\title{
TRANSFORMACJA TOŻSAMOŚCI MNIEJSZOŚCI NARODOWEJ W WARUNKACH ISTOTNYCH ZMIAN POLITYCZNYCH NA PRZYKŁADZIE UKRAIŃCÓW PODLASIA
}

Celem artykułu jest ukazanie procesów komplikowania się struktur narodowych oraz ewolucji tożsamości narodowej na obszarze wschodniego pogranicza $\mathrm{w}$ warunkach przemian politycznych, społecznych i kulturowych, jakie dotykały te tereny na przestrzeni ostatnich kilkudziesięciu lat. Chciałbym w związku z tym w artykule odnieść się zarówno do badań historyków, jak i badań własnych, jakie przeprowadziłem wśród mniejszości ukraińskiej w województwie podlaskim w 2011 oraz 2015 roku. Dynamiczny fenomen narodowy, jakim jest mniejszość ukraińska w województwie podlaskim, moim zdaniem, ukazuje, w jaki sposób, pod wpływem jakich czynników, wydarzeń i w jakim kierunku może zmieniać się zarówno obraz narodowościowy danego regionu oraz tożsamość etniczna i narodowa danej grupy. Chciałbym zwrócić uwage, jak wielki wpływ na procesy narodowe i tożsamościowe ma zarówno sytuacja polityczno- społeczna w kraju zamieszkiwania mniejszości, w kraju macierzystym, jak i sytuacja geopolityczna w regionie.

Tożsamość narodową i etniczną rozumiem jako zmienną, płynną i często wielowarstwową. W sposób oczywisty opartą na kulturze i pochodzeniu, ale z drugiej strony zależną od autorefleksji i świadomości jednostki. W swojej książce Ukraińcy Podlasia. Dylematy tożsamościowe [Nikitorowicz 2014] koncepcję przemian tożsamości narodowej opieram zarówno na pracach Antoniny Kłoskowskiej [1996], Andrzeja Sadowskiego [1995] i Zygmunta Baumana. Opisując w niniejszym artykule zanikanie i odtwarzanie, rewitalizację ukraińskiej tożsamości na terenach dzisiejszego województwa podlaskiego zwracam szczególną uwagę na zmienność tożsamości 
jako jej cechę charakterystyczną w obecnych czasach oraz na jej powiązania $\mathrm{z}$ indywidualnymi i świadomymi decyzjami poszczególnych osób.

Pierwsza część artykułu dotyczy historycznych korzeni „Ukraińców Podlasia”, a druga jest związana z badaniami, jakie przeprowadziłem w 2011, chcąc poznać proces odtwarzania się tej mniejszości w regionie oraz badaniami z 2015 roku, w trakcie których postawiłem pytanie dotyczące wpływu sytuacji politycznej na Ukrainie na tożsamości nowo powstałej i ciągle kształtującej się mniejszości.

Historycy w swych badaniach dowodzą, że ziemie dzisiejszego województwa podlaskiego, wchodzącego w skład historycznego Podlasia, były zasiedlane już w wiekach XI-XII, zarówno przez ludność rzymskokatolicką z Mazowsza, jak i ludność prawosławną z Rusi (dzisiejsza Ukraina). Jako najstarsze grody ruskie na tych ziemiach podaje się Drohiczyn (XI wiek) oraz Brześć, Mielnik, Siemiatycze, Bielsk czy Suraż. Kolejne fale osadnictwa Rusinów pochodziły głównie z Wołynia. Procesy osadnicze z różnym natężeniem trwały aż do końca XVIII wieku [Gloger 1903; Hawryluk 1993, 1999; Wiśniewski 1977; Makarski 1996; Barwiński 2011]. Już w XV wieku widoczne stały się różnice i granice między regionami zasiedlanymi przez ludność o odmiennej religii i języku. „Cały zachód, stanowiący niegdyś część Mazowsza, zasiedliła ludność polska, przeważnie drobnoszlachecka. Część południowo-wschodnią zasiedliła we wsiach chłopskich i miastach ludność ruska nadbużańska, pochodzenia północno-ukraińskiego. Część północno-wschodnią objęła w swe posiadanie białoruska ludność znad Niemna i znad Rosi z dużą domieszką litewską i zapewne, także z potomkami uchodźców jaćwieskich" [Wiśniewski 1977]. Bardzo szybko wykształciły się więc granice obszarów etnicznych na Podlasiu, które z biegiem lat ulegały jedynie niewielkim zmianom.

Pierwsze oficjalne szacunki dotyczące liczebności ludności ruskiej na obszarach dzisiejszego województwa podlaskiego zostały opracowane przez spis i statystykę pruską z 1800 roku. Według tamtych danych na tych terenach zamieszkiwało około 40 tys. Rusinów [Hawryluk 1999]. Jeszcze większą liczbę ludności o tym pochodzeniu etnicznym wskazuje pierwszy rosyjski spis powszechny na tych ziemiach z 1897 roku, w którym pytano badanych zarówno o język ojczysty, jak i o wyznanie. W ówczesnym obwodzie białostockim oficjalnie mieszkało 60335 Rusinów (99,8\% w powiecie bielskim) wobec jedynie 5909 osób uznanych za Białorusinów [Wakar 1917].

Całkowite odwrócenie tych wyników następuje w okresie międzywojennym w świetle kolejnych badań i spisów ludności. Zarówno dane po- 
chodzące ze spisu z 1921 roku jak i 1931 roku sugerują praktyczny zanik tożsamości rusińskiej czy ukraińskiej na terenie dzisiejszego województwa podlaskiego. Zwraca uwagę natomiast pojawiająca się ogromna liczba osób deklarujących używanie języka „prostego”, białoruskiego lub przynależność właśnie do tej grupy narodowościowej.

W tamtym czasie miejscowa ludność wiejska miała bardzo słabo rozwinięte poczucie tożsamości narodowej czy nawet etnicznej. Istniejące różnice postrzegano głównie na zasadach przynależności religijnej, co odróżniało miejscową ludność pochodzenia ukraińskiego od Ukraińców z Galicji czy Wołynia. Jerzy Wiśniewski [1977] w ten sposób próbuje tłumaczyć ten fenomen: „Miejscowi określali ludność ruską w powiecie bielskim jeszcze w początkach XX wieku jako Rusinów lub Ukraińców. Bardzo możliwe, że osiedlenie się wśród nich autentycznych Białorusinów, działalność urzędników i popów białoruskiego pochodzenia spowodowała, że zaczęto ich uważać za Białorusinów”. Faktem jest, że wbrew oficjalnym wynikom spisów wielu polskich badaczy kwestionuje i podważa w owym okresie możliwość tak gwałtownych zmian struktury etniczno-narodowościowej na tym obszarze. Zarówno A. Krysiński [1928] jak i J. Tomaszewski [1985] podkreślają, że ludność prawosławna żyjąca między Narwią a Bugiem jest niewątpliwie pochodzenia ukraińskiego. Leon Wasilewski [1927] podkreśla, że „powiat Bielski wykazuje 30,5\% Białorusinów będących w rzeczywistości Ukraińcami językowo”.

Okres powojenny, w przypadku prawosławnej społeczności dzisiejszego województwa podlaskiego, wiąże się z promowaniem, także przez ówczesną władzę, stereotypu „prawosławny - Białorusin” oraz uznaniem gwary ukraińskiej za gwarę białoruską.

Współcześnie obszar województwa podlaskiego jest pograniczem, gdzie od wielu wieków współistniały i przenikały się różne języki, kultury i religie. Mamy tu do czynienia z językami i narodowościami: polską, białoruską, ukraińską, rosyjską czy litewską. Duża część mieszkańców uległa asymilacji do kultury dominującej, jednak ciągle bardzo wielu jest świadomych swojej odrębności i stara się pielęgnować, nie dopuścić do zaniku miejscowych dialektów i gwar. To zróżnicowanie w ciągu wielu wieków, zmian granic i zwierzchności państwowej nad tymi terenami uległo jeszcze większym komplikacjom świadomościowo-narodowościowym. Bardzo trafnie zauważa to M. Koter [1995], który pisze, że „na pograniczu białorusko-ukraińskim (także w granicach Polski) podobieństwo kulturowe pomiędzy tymi dwoma prawosławnymi narodami jest tak silne, że ich formalne rozgraniczenie staje się niemożliwe. W rejonie Bielska Podlaskiego i Hajnówki zdarza 
się, że na skutek różnych sytuacji życiowych oraz poddania się odmiennej propagandzie politycznej, w obrębie tej samej rodziny ojciec jest „tutejszy”, jeden syn uważa się za Białorusina, drugi za Ukraińca, a wyemancypowana córka deklaruje się jako Polka”.

Dzisiaj naukowymi dowodami na pochodzenie etniczne dużej części mieszkańców województwa podlaskiego są badania prowadzone w drugiej połowie XX wieku nad językiem i dialektami miejscowej ludności. „Województwo białostockie nie jest jednolite pod względem językowym. $\mathrm{Na}$ znacznej jego części występują gwary wschodniosłowiańskie: na północy białoruskie, na południu ukraińskie, a pomiędzy nimi przejściowe białorusko-ukraińskie. W pasie zachodnim niemal wyłącznie są gwary polskie, dalej na wschód ludność jest przeważnie dwujęzyczna, w wielu wsiach gwara polska współistnieje $\mathrm{z}$ gwarą białoruską lub ukraińską. Wzajemny stosunek dwóch współistniejących gwar układa się bardzo różnie" [Atlas gwar wschodniosłowiańskich Białostocczyzny, 1980]. Warto jednak od razu zaznaczyć, że naukowo stwierdzone, praktycznie powszechne występowanie gwar ukraińskich na południowym obszarze województwa podlaskiego nie przekłada się bezpośrednio na powszechne występowanie świadomości czy tożsamości ukraińskiej między Bugiem a Narwią. Mimo coraz większej świadomości pochodzenia języka, duża część ludności pozostaje przy dotychczasowych kategoryzacjach, a ich zmiany są bardzo powolne. Proces rewitalizacji tej grupy mniejszościowej $\mathrm{w}$ województwie podlaskim nie został jeszcze zakończony, a możliwości jego ostatecznego przebiegu ciągle są sprawą otwartą, choć obecnie coraz bardziej klarowną.

Liczba świadomych przedstawicieli mniejszości ukraińskiej w województwie podlaskim w 2011 roku przekroczyła 2200 osób i jest to jedyna mniejszość narodowa w województwie podlaskim, która zanotowała wzrost w latach 2002-2011 [http://www.stat.gov.pl/bialystok/69_1078_PLK_HT ML.htm, 2013]. Na terenie województwa podlaskiego działają dwa stowarzyszenia ludności ukraińskiej: Związek Ukraińców Podlasia oraz Związek Ukraińskiej Młodzieży Niezależnej. Związek Ukraińców Podlasia (ZUP) działał początkowo $\mathrm{w}$ ramach ogólnopolskiej organizacji mniejszości ukraińskiej - Związku Ukraińców w Polsce i był oddziałem organizacji. Jednak bardzo szybko, bo już 22 marca 1992 roku nastąpiło oderwanie i usamodzielnienie się organizacji - powstał Związek Ukraińców Podlasia. Separacja nastąpiła pod wpływem sprzeczności i kształtowania odmiennych celów i działań organizacji na tle lingwistyki, etnografii oraz wyznania [Misiejuk 2004]. 
Cyklicznie jest organizowanych wiele imprez kulturalnych łączących miejscowy folklor i tradycję z ogólnie pojmowaną kulturą mniejszościową i ukraińską. Największą jest Festiwal Kultury Ukraińskiej na Podlasiu - „Podlaska Jesień” odbywający się nie tylko w Bielsku Podlaskim, ale również między innymi w Białymstoku, Siemiatyczach czy Czeremsze. Równie popularną i znaną $\mathrm{w}$ regionie imprezą kulturalno-folkową organizowaną przez ZUP jest „Na Iwana, na Kupała” organizowaną nad zalewem w Dubiczach Cerkiewnych. Impreza ma już kilkunastoletnią tradycję, pierwszy raz odbyła się bowiem w 1996 roku nad Narwią. Nad zalewem Bachmaty w Dubiczach Cerkiewnych odbywa się od 1998 roku.

Bardzo ważną częścią realizacji celów, stawianych w statucie organizacji, jest wydawanie przez ZUP periodyku „Nad Buhom i Narwoju”. Publikowane w nim artykuły dotyczą życia kulturowego, religijnego i politycznego miejscowej ludności pochodzenia ukraińskiego. W piśmie przedstawiane są zarówno wątki historyczne, jak i aktualne wydarzenia dotyczące ludności ukraińskojęzycznej w województwie podlaskim.

Związek Ukraińców Podlasia od początków swojej działalności dążył do uruchomienia ukraińskojęzycznego programu telewizyjnego, który relacjonowałby istotne fakty i wydarzenia $\mathrm{z}$ życia miejscowej ludności oraz przedstawiał punkt widzenia i pomagał w szerzeniu świadomości i tożsamości wśród mieszkańców województwa podlaskiego posługujących się gwarą języka ukraińskiego. Program miał być nadawany w języku mniejszości z jednoczesnym tłumaczeniem na język polski w postaci napisów [Ryżyk, Kuprianowicz 1992, nr 3: 31]. Program zaczął się ukazywać od 1995 roku, jeszcze w ramach Warszawskiego Ośrodka Telewizji. Po powstaniu Białostockiego Ośrodka Telewizji program o nazwie „Ukraiński Przegląd” ukazuje się w ramach bloku tematycznego dotyczącego wszystkich mniejszości województwa o nazwie "Sami o sobie”. Program relacjonuje wydarzenia kulturalne społeczności, bieżącą działalność ZUP, prezentowane są felietony dotyczące miejscowej tradycji, religii, folkloru.

Przedstawiciele mniejszości ukraińskiej w województwie podlaskim prowadzą od 1991 roku w Radiu Białystok program „Ukraińska Dumka”, który emitowany jest trzy razy w tygodniu. Od 2009 roku w regionalnym radiu Orthodoxia emitowana jest raz w tygodniu audycja w języku ukraińskim przygotowywana i prowadzona przez osoby związane z mniejszością ukraińską w województwie podlaskim.

Warto zaznaczyć, że ostatnie lata przyniosły również spore sukcesy na gruncie narodowej edukacji mniejszości ukraińskiej w województwie pod- 
laskim. Zarówno w Bielsku Podlaskim, jak i Białymstoku powstały klasy w szkołach podstawowych i średnich umożliwiające naukę języka ukraińskiego i poznawanie tej kultury. W Bielsku Podlaskim powstało przedszkole z nauką języka ukraińskiego, gdzie dodatkowo realizowany jest projekt „Do źródeł”. Polega on na tym, że dzieci na nietypowych zajęciach poznają ukraińskie kolędy, język, zwyczaje i obrzędy rocznego cyklu kalendarzowego. W projekcie bierze udział 114 dzieci, czyli ponad połowa uczęszczająca do Przedszkola nr 9 w Bielsku Podlaskim.

Pod patronatem ZUP działa kilka amatorskich zespołów artystycznych, w których uczestniczą dzieci i młodzież ze szkół oraz przedszkola, gdzie naucza się języka ukraińskiego. Zespoły te zajmują się głównie pielęgnacją i propagowaniem miejscowego folkloru i związanymi z nim piosenkami czy obrzędami. Warto wymienić zespoły: „Rodyna” z Dubiażyna, młodzieżowy „Ranok” z Bielska Podlaskiego, „Strumok” z Dubicz Cerkiewnych, „Hiłoczkę" z Czeremchy, „Tyrsę” z Kleszczel.

Przedstawiciele i działacze ZUP, również w ostatnich latach, rozpoczęli działalność nie tylko kulturowo-instytucjonalną, ale również polityczną. Ta aktywność znalazła odzwierciedlenie w życiu politycznym regionu. Przedstawiciele Związku Ukraińców Podlasia osiągali sukcesy w wyborach samorządowych, zasiadając $w$ radach miast i gmin oraz pełniąc różne funkcje samorządowe - wójta, zastępcy burmistrza, przewodniczącego rady miasta w miejscowościach położonych głównie w południowej części województwa podlaskiego.

Współcześni Ukraińcy w województwie podlaskim spotkali się z odmiennymi problemami kształtowania i rewitalizacji własnej tożsamości w stosunku do pozostałych grup mniejszości ukraińskiej z innych regionów kraju. Po pierwsze, nie dotknęła ich akcja „Wisła”, co w bardzo znaczącym stopniu ułatwiło kontynuowanie i pielęgnowanie tradycji kulturowo-językowych. Nie zostało im odebrane poczucie bycia ludnością "tutejszą”. W odróżnieniu od przedstawicieli mniejszości ukraińskiej w innych regionach kraju, Ukraińcy na Podlasiu związani są li tylko z prawosławiem, co również może stanowić o ich specyficznej i nieco odmiennej strukturze tożsamości. Jednocześnie zostali zmuszeni do podjęcia wyzwania dotyczącego przebudowy stereotypu mówiącego, iż każdy prawosławny mieszkaniec województwa podlaskiego jest Białorusinem. W przeciwieństwie do swoich pobratymców w innych regionach kraju Ukraińcy na Podlasiu nie są osamotnieni w „inności”, co zrodziło odmienne problemy tożsamościowe nie tylko związane z asymilacją do polskości. „Dotąd mó- 
wiliśmy: Białorusini, ale to nie od dawna. Teraz coraz częściej mówi się: Ukraińcy. Dwa bratnie narody. Ale kto jest kto? Moi ruscy pradziadowie nie zaprzątali sobie tym głowy. Ich sens życia zawierał się w pracy własnych rąk. Nad nimi zawsze było to samo słońce, ten sam widok ich otaczał, rok regulowany świętami religijnymi był uporządkowany. Byli wśród swoich" [Sajewicz 2001].

Tożsamość traktowana jako jedna $\mathrm{z}$ „najbardziej uniwersalnych ludzkich potrzeb, potrzeb przynależności lub bycia akceptowanym, potrzeb bezpieczeństwa" [Baumann 1993: 8], jako ukraińska zaczęła się kształtować dosyć późno wśród mieszkańców południowo- wschodniej części województwa podlaskiego. Dopiero w latach osiemdziesiątych i dziewięćdziesiątych XX wieku, ze względu na demokratyzację życia społecznego oraz lepszego poznawania, opisu dialektów i gwar ukraińskich na Podlasiu, rozpoczęło się na tych terenach dość intensywne poszukiwanie i budowanie etnosu ukraińskiego. „Poszukiwanie tożsamości jest najbardziej intensywne wówczas, gdy nie jest ona "dana” jako dar krwi i ziemi, lecz gdy jest płynna, plastyczna” [Baumann 1993: 9]. Bardzo dobrze opisują to poszukiwanie słowa jednego z przedstawicieli badanej grupy: „Oczywiście, że nie od zawsze czułem się Ukraińcem. Moja ukraińskość pojawiła się od zaprzeczenia białoruskości, dlatego, że ja jestem tym pierwszym pokoleniem studiującym na przełomie lat 70. i 80., które, że tak powiem, dostało argumenty żeby powiedzieć, że nas ordynarnie oszukują, wmawiają nam ciemnotę, bo my tacy nie jesteśmy. Poszedłem na studia, poznałem ludzi podobnych do mnie, zaczęliśmy rozmawiać, czytać, a no i jak miałem te 18 czy 20 lat to pojawił się „Atlas gwar wschodniosłowiańskich Białostocczyzny”. Do tej pory gdzieś oficjalnie, słyszałem tylko, że my rozmawiamy po białorusku. Wziąłem ten atlas, czytam i co tu się okazuje? Żaden to jest białoruski, tylko ukraiński. A wcześniej była taka sytuacja, że byliśmy odcięci od szkoły, od literatury - kompletna izolacja. Ktoś tam chciał nas przekręcić jak na jakiejś maszynce. To się nie udało - na szczęście. To się właśnie zaczęło od zaprzeczenia białoruskości, bo to nie była nasza tożsamość. To się zaczęło od odkrywania korzeni. Ta tożsamość zaczęła się w drodze poszukiwań”. Mniejszość ukraińska w województwie podlaskim budując swój status narodowy/etniczność (tożsamość, świadomość) napotyka więc na istotne problemy. $Z$ jednej strony mamy do czynienia z problemem „oderwania się od białoruskości”, a z drugiej $\mathrm{z}$ bardzo niejasnym etnosem ukraińskim.

W związku z tą szczególną sytuacją tożsamość Ukraińców w województwie podlaskim koncentruje się wokół kilku podstawowych zmiennych, 
które zaprezentuję na podstawie badań własnych, jakie przeprowadziłem w 2011 roku. Badanie polegało na przeprowadzeniu 54 wywiadów pogłębionych z przedstawicielami grupy.

Według przedstawicieli mniejszości ukraińskiej w województwie podlaskim każdy ma jakiś naród, ale nie każdy trafnie go uświadamia. Wśród badanych dominują poglądy związane $\mathrm{z}$ naturalistycznym (lub obiektywistycznym) rozumieniem narodu i przynależności narodowej. „I urodzenie i osobisty wybór jest ważne, to znaczy, że z jednej strony to, czy jesteśmy członkiem takiego czy innego narodu musi być w jakiś sposób zdeterminowane, musi być uzasadnione. Nie może być ni z gruszki, ni z pietruszki. Oczywiście najlepiej, że ten wybór nasz jest oparty na genezie genetycznej. Z czegoś tam pochodzimy i się wywodzimy. Rzecz jasna, że wybieramy w końcu sobie przynależność narodową, bo będąc członkiem jednego narodu na przykład zmieniają się nazwy: chociażby w naszym przypadku. Pięćdziesiąt czy sto lat temu byliśmy Rusinami, a dziś już takiej narodowości nie ma i co tu mówić o wyborze? Zresztą taka kategoria przestała istnieć. Dzisiaj musimy się nazywać inaczej, bo dzisiaj jest inna sytuacja i to wszystko inaczej wygląda. Jak chcemy działać i istnieć odrębnie to i inaczej się nazywamy" (W25). Podejście, zgodnie z którym osobisty wybór musi być poparty cechami obiektywnymi oraz pochodzeniem jest $z$ jednej strony związane $\mathrm{z}$ historycznymi zawirowaniami, jakim poddana była ta grupa, a $\mathrm{z}$ drugiej strony rozległym etnosem ukraińskim, do którego działacze Związku Ukraińców Podlasia ciągle się odwołują. W świadomości respondentów pojawia się więc nowa kategoria przynależności narodowej, przynależności potencjalnej lub nieuświadomionej. Jest to zrozumiałe w warunkach bardzo częstych autentycznych kłopotów respondentów z określeniem swojej przynależności narodowej. Przekonania społeczne o funkcjonowaniu ukrytej lub nieuświadamianej przynależności narodowej są ewidentnym wskaźnikiem, iż procesy narodotwórcze na badanym obszarze nie zostały ugruntowane, a tym bardziej jakoś zakończone. „Jest to na pewno z jednej strony ludność ukraińskojęzyczna, ale bez wykrystalizowanej świadomości narodowej albo nawet ze świadomością białoruskiej. Ale za tą świadomością białoruską nie idą wartości, tradycje, język i literatura. To taka ludność o świadomości etnicznej, bardziej prawosławnej czy ruskiej, która posługuje się gwarami ukraińskimi, związana jest z kulturą ukraińską, ale świadomości ukraińskiej nie ma. Więc nie będę nazywała ludzi, którzy nie czują się Ukraińcami, Ukraińcami. Tych nieświadomych to co najwyżej ludność właśnie ukraińskojęzyczna, a tą drugą grupę, która 
zbudowała na bazie atrybutów swoją tożsamość ukraińską, to są po prostu Ukraińcy na Podlasiu czy Ukraińcy prawosławni” (W23).

Sami zainteresowani określali i postrzegali siebie, jeszcze w 2011 roku, jako „Ukraińców Podlasia”, grupę spójną i wyraźną, opierającą się na takich wyróżnikach, jak: język w postaci archaicznej gwary, autochtoniczność, miejscowa kultura ludowa i zwyczaje oraz wyznanie prawosławne. Współczesna tożsamość etniczno-narodowa badanej grupy opiera się również w znacznej mierze na oderwaniu i przeciwstawieniu własnej grupy narodowościowej Białorusinom oraz na silnym przywiązaniu do małej ojczyzny, czyli terenów między rzekami Bug i Narew. W związku z tym w województwie podlaskim widoczny jest swoisty konflikt pomiędzy mniejszością białoruską i ukraińską, gdyż każda z nich odwołuje się do tej samej ludności, a zaszłości historyczne sprawiają, że miejscowa ludność często stoi przed ciężkimi wyborami. „Moja świadomość bycia Ukraińcem zaczęła się może nie tyle od zaprzeczenia białoruskości, co bardziej poszukiwania, choć zaprzeczanie też było. Ja kończyłem liceum, teraz chyba też tak się nazywa, z białoruskim językiem nauczania. Przez cztery lata się tego uczyłem, później też była matura, ale jakoś nigdy nie przyjmowałem tego jak czegoś swojego i oczywistego. W momencie studiów czy pod koniec liceum pojawiły się pewne pytania powstałe $\mathrm{w}$ konfrontacji z pojawiającymi się informacjami. Wtedy pojawiło się „Nad Buhom i Narwoju”, wtedy zaczęto wydawać, programy w radiu i telewizji dotyczące tematyki Ukraińców na Podlasiu. I w konfrontacji z tymi informacjami, tak jak mówię, te poszukiwania poszły w stronę ukraińskości. Dalej były studia i tutaj dalej się z wieloma ludźmi rozmawiało, poznawało, wyjeżdżało. I już na studiach ta tożsamość została skrystalizowana” (W17). W związku z powyższym podstawowymi składnikami tożsamości ukraińskiej w regionie, a jednocześnie cechami umożliwiającymi budowanie granic oddzielających mniejszość ukraińską i białoruską stały się język jako gwara, pochodzenie oraz teren zamieszkiwania. „Oczywiście kwestie językowe. Ludność ukraińska mówi po ukraińsku, gwarą, a białoruska po białorusku. Są nieco inne zwyczaje. $\mathrm{Na}$ terenach etniczno-białoruskich występują pewne zwyczaje, które nie występują na terenie ukraińskim i na odwrót. Inna była też migracja tej ludności. Według badań naukowców, historyków, ludność ukraińska przybyła z południa głównie z Wołynia czy z Ziemi Brzeskiej, a ludność białoruska z północno-wschodniej części, znad Niemna. Z tym, że ogromna grupa ludzi świadoma narodowo wszczęła czyn, która uważa się za Białorusinów, pochodzi z terenów etnicznie ukraińskich i stąd tutaj wychodzi duże za- 
mieszanie. Często jest tak, że osoby, które etnicznie pochodzą z terenów ukraińskich, uważają się za Ukraińców lub częściej za Białorusinów i tutaj jest paradoks w tej sytuacji na Podlasiu" (W4).

Przedstawiciele mniejszości ukraińskiej w województwie podlaskim w 2011 roku charakteryzowali się również bardzo małym stopniem powiązania z Ukrainą jako ojczyzną. Rzadko, jeżeli w ogóle, były wymieniane kulturowe aspekty powiązań, a większość badanych deklarowała brak kontaktów i wspólnych interesów z samą Ukrainą jak i jej obywatelami. Badani podkreślali też silną potrzebę autonomii „Ukraińców Podlasia” w stosunku do pozostałej części Ukraińców w Polsce oraz przywiązanie do religii prawosławnej. „Oczywiście, powinniśmy utożsamiać się tak naprawdę z jedną grupą narodową - ukraińską. Mamy wspólne pochodzenie, podstawy, aby tak sądzić. Natomiast na dzisiaj jesteśmy jednak taką grupą, która różni się od Ukraińców z innych regionów Polski. Chociażby poprzez tą ostatnią historię, poprzez te zawieruchy, które dotknęły tą ludność na południe od Bugu. Ludność ta, która jest na północ od Bugu, nie doświadczyła w historii najnowszej tego typu zdarzeń, choć dotknęło nas coś innego - ta właśnie tutaj białorutenizacja. Być może ona bardziej wpływa na zanik, czy też jest większym zagrożeniem dla tej grupy naszej niż to, co stało się na Podlasiu południowym tam na południu. Chociaż od razu zaznaczę, że nie można tego tak jednoznacznie i dokładnie powiedzieć, nie ma całościowego porównania, tam działy się rzeczy drastyczne dla tej ludności. Jeszcze trzeba powiedzieć o religii czyli wyznanie Prawosławne u nas, no i gwara a nie język literacki. I ja myślę, że My jesteśmy bardziej związani z tym, tutaj regionem, naszym czyli między Bugiem a Narwią a nie państwem Ukrainą" (W9).

Badania z 2011 roku potwierdziły hipotezę o autentycznym narastaniu podmiotowości zbiorowości ukraińskiej w województwie podlaskim, a same procesy narodotwórcze przynajmniej na etapie początkowym obejmowały przede wszystkim konsolidację wewnętrzną zbiorowości oraz tworzenie instytucji mniejszości narodowej.

W obecnej sytuacji geopolitycznej i w obliczu wojny na Ukrainie zasadnym wydało mi się przeprowadzenie kolejnych badań, które dałyby mi materiał porównawczy oraz odpowiedziały na kilka pytań dotyczących wpływu obecnej sytuacji na Ukrainie na rozwój tożsamości narodowej mniejszości ukraińskiej w województwie podlaskim. Założyłem, że kierunki zmiany mogą podążać w trzech kierunkach: 1) utrzymanie dystansu i autonomii wobec wydarzeń na Ukrainie; 2) włączanie się w nurt wydarzeń, wzrost nastrojów nacjonalistycznych oraz narastanie tożsamości ukraińskiej; 
3) ucieczka poprzez dalsze zbliżenie i integracja $\mathrm{z}$ większością polską. Badanie polegało na przeprowadzeniu 17 wywiadów pogłębionych z przedstawicielami mniejszości ukraińskiej w województwie podlaskim.

Z przeprowadzonych badań wynika, że nastąpił „Zwrot” „Ukraińców Podlasia” w kierunku samej Ukrainy. Widoczna jest zmiana podejścia respondentów i wysoki wzrost zainteresowania sytuacją na Ukrainie. W zasadzie wszyscy badani śledzili sytuację na Ukrainie, mieli dostęp do ukraińskich mediów oraz interesowali się informacjami płynącymi z tamtejszych portali internetowych. Wyrażali nie tylko chęć i deklaracje pomocy, ale i działań, których przykładem jest przyjęcie podczas wakacji dzieci z rejonów zagrożonych walkami. Respondenci mieli jasne i klarowne przemyślenia i uwagi na temat sytuacji na Ukrainie, a sama Ukraina była w znacznie większym stopniu niż w poprzednim badaniu postrzegana jako „ojczyzna ideologiczna”.

Respondenci $\mathrm{w}$ niewielkim stopniu podkreślali potrzebę utrzymania znacznej autonomii wobec Związku Ukraińców w Polsce. Zaznaczył się wyraźny podział na dwie grupy. Jedni uważają, że pozostawanie w autonomii jako Związek Ukraińców Podlasia jest korzystne, drudzy skłaniają się w kierunku większej współpracy i integracją ze ZUwP. Wszyscy badani jednoznacznie opowiadali się za wizją Ukrainy europejskiej i prozachodniej. „Ja wiem tak zakulisowo, że całym powodem utworzenia Związku Ukraińców Podlasia było to, że większość Ukraińców w Polsce to są ludzie wyznania unickiego. Tutaj natomiast na Podlasiu to są, my jesteśmy prawosławni. I tutaj był ten główny rozdział. Ale teraz ja i nie tylko ja uważam, że w interesie ruchu jest nam potrzebna jedna, wspólna reprezentacja i działanie. Jak się widzi, co się dzieje na szczeblach krajowych, się rozmawia i mówi o Związku Ukraińców to nikt nie pamięta i nie wie, że istnieje Związek Ukraińców Podlasia. Także dla mnie jest to bardzo niekorzystna sprawa, nikt o nas nie pamięta i się nas po prostu pomija. I ja uważam, że tak jak i niektóre towarzystwa Łemków są częścią Związku Ukraińców w Polsce, tak i my powinniśmy być tylko, że z jakąś małą autonomią regionalną. Wtedy i więcej możemy, w jedności siła i ten podział jest taki sztuczny, bo kulturowo i tak z nimi współpracujemy i się cały czas wymieniamy, przyjeżdżamy do siebie i razem robimy wydarzenia kulturalne" (W3).

Religia prawosławna dla badanych nie jest już tak ważnym elementem w ramach budowania własnej tożsamości narodowej. Dzisiaj jest to powód do podziałów w społeczności lokalnej, a wynikające z przynależności religijnej konotacje - jedną z barier rozprzestrzeniania się tożsamości ukraińskiej w województwie podlaskim. Badani zaznaczali widoczne podziały 
wśród miejscowej ludności prawosławnej, która jest etnosem, do którego działacze ruchu się odwołują i z którego pochodzą jego wszyscy przedstawiciele. Podziały te korespondują $\mathrm{z}$ widocznym dzisiaj podziałem ruskiego świata na Ukrainie [Riabczuk 2005]. Sugerowano negatywny stosunek duchownych prawosławnych oraz ich poparcie dla Rosji. „Świadomość jest mocno kształtowana przez media, a wiadomo, że tutaj u nas jak ktoś ma w sobie kulturę i korzenie ukraińskie, to jest prawosławny. Cerkiew natomiast twardo stoi po stronie moskiewskiej i nie kryje tego. Jeżeli ktoś słucha duchownych i dodatkowo w naszym rejonie poogląda telewizję, to niestety, ale na pewno będzie się odwracał od naszej sprawy, od bycia Ukraińcem. I ja to wręcz czuję, że wśród prawosławnych gros tych ludzi, którzy z nami sympatyzowali, czy nawet mogliby poczuć się, tą świadomość i już nawet niektórzy się po części czuli bo i rozmawiali «po swojemu» i przychodzili, czytali, to teraz się odwraca. Ja w tym towarzystwie prawosławnym to czuję niestety i widzę” (W9) oraz „Sytuacja zagrożenia/wojny na Ukrainie nie ma aż tak wielkiego wpływu na kształtowanie się świadomości ukraińskiej w województwie podlaskim. Wydaje się jednak, że ma widoczny wpływ na polaryzowanie się bardziej skrajnych postaw wśród ludności prawosławnej regionu $-\mathrm{z}$ jednej strony unaocznienie się postaw prorosyjskich i antyukraińskich, z drugiej - większej solidarności i poparcia dla narodu ukraińskiego" (W1).

Respondenci deklarowali, że na ogół nie zauważają intensyfikacji postaw skrajnych, nacjonalistycznych wobec Ukraińców Podlasia, zarówno wśród przedstawicieli grupy własnej, jak i grupy większościowej. W wywiadach widoczne były jednak dosyć silne postawy antyrosyjskie wśród świadomych Ukraińców w województwie podlaskim oraz poparcie dla polityki prowadzonej przez Petra Poroszenkę.

Badanie wskazało również na problem stopniowego zanikania gwary ukraińskiej w województwie podlaskim, która była czynnikiem inicjującym odradzanie się tej zbiorowości w województwie oraz czynnikiem odróżniającym zarówno w stosunku do mniejszości białoruskiej w regionie, jak i pozostałych Ukraińców w Polsce posługujących się głównie ukraińskim językiem literackim. Podkreślano, że młodzież ukraińska, w regionie kształcąca się w przedszkolu i szkołach w zakresie języka literackiego, nie poznaje w zasadzie gwary i nią nie mówi. „Jak ja się zapytałam kiedyś ojca, w jakim języku my mówimy, jaki jest nasz język ojczysty to On mi odpowiedział po „hahłacku” i tak się mówiło albo, że po swojemu albo po hahłacku. I później ktoś to nazwał, że to nie „hahłacki” tylko ukraiński. A dzisiaj dzieci nie mają tego dylematu, one się uczą w szkole literackiego ukraińskiego i wiedzą od 
razu co i jak i kim są. Niestety ta gwara zanika, ja jeszcze z mężem mówię gwarą i między sobą bardzo często i nawet do dzieci. Ale z nimi to częściej po polsku, zresztą jak już coś to ja do nich gwarą, a oni ukraińskim odpowiadają. Świadomość młodych jest fajna, dobra, oni się nie wstydzą ale oni uważają się po prostu za Ukraińców i Polaków, a nie, że my jeszcze miejscowi. Ja mam trójkę dzieci i jest tak, że oni świadomość mają, ale gwarą nie rozmawiają i ona niestety pewnie zostanie w muzeum w skansenie. Dzieci w Orli i okolicach nie rozmawiają już w ogóle w gwarze, dzieci co najwyżej uczą się literackiego w szkole" (W8).

Podsumowując wyniki najnowszych badań należy stwierdzić, że obecna sytuacja na Ukrainie w sposób widoczny wpłynęła na przyspieszenie oraz ukierunkowanie przemian tożsamościowych wśród mniejszości ukraińskiej w województwie podlaskim. Widoczny jest częściowy rozpad dotychczasowej tożsamości i niektórych jej elementów takich, jak: odwołania do religii prawosławnej, miejscowej gwary czy potrzeby autonomii wobec Związku Ukraińców w Polsce. „Ukraińcy Podlasia” oraz ludność, do której ta grupa się odwołuje i która stanowi jej naturalny etnos, ulega dzisiaj podziałowi i rozpadowi, który z jednej strony cechuje się postawami nacjonalistycznymi oraz silnym zbliżeniem do Ukrainy albo z drugiej strony postawą ucieczki w polskość lub białoruskość, której bliżej dzisiaj do świata prawosławnego. W związku z tymi podziałami rysuje się również, w oczach respondentów, widoczny rozbrat pomiędzy narodem a religią oraz upadek mitu jednego ruskiego świata. Ważne jest również to, że „Ukraińcy Podlasia” reprezentują li tylko proeuropejską wizję Ukrainy.

Mniejszość ukraińska w województwie podlaskim jest grupą bardzo interesującą z punktu widzenia badacza spraw narodowościowych oraz tożsamościowych. W przeciągu ostatnich dziesięcioleci ludność ta podlegała ogromnym i znamiennym przemianom świadomościowo-tożsamościowym, które najczęściej wynikały i łączyły się ze zmianami w sferze geopolitycznej regionu. Ciekawie jest prześledzić szlak, jaki przeszła ewolucja tożsamości narodowej mniejszości ukraińskiej w województwie podlaskim i jednocześnie stwierdzić, że ów proces jeszcze się nie zakończył. Niewątpliwie ruch odrodzenia ukraińskiej tożsamości w województwie zapewnił sobie trwałe miejsce na mapie narodowościowej regionu, a sama grupa poprzez swoje działania oraz zwiększającą się liczbę świadomych członków jest widoczna. Jednak jednocześnie należy stwierdzić, że tożsamość narodowa grupy ciągle się kształtuje i ulega przemianom zarówno pod wpływem czynników zewnętrznych, jak i wewnętrznych. 


\section{Bibliografia}

Barwiński M. (2011), Ukraińcy na Podlasiu - geneza, kontrowersje, współczesność, „Acta Universitatis Lodziensis Folia Geographica Socio-Oeconomica”, nr 11.

Bauman Z. (1996), Socjologia, tłum. J. Łoziński, Poznań.

Gloger Z. (1903), Geografia historyczna ziem dawnej Polski, Kraków.

Hawryluk J. (1999), Kraje ruskie Bielsk, Mielnik, Drohiczyn. Rusini - Ukraińcy na Podlaszu - fakty i kontrowersje, Kraków.

Koter M. (1995), Ludność pogranicza - próba klasyfikacji genetycznej, „Acta Universitatis Lodziensis. Folia Geographica”, nr 20.

Kłoskowska A. (1996), Kultury narodowe u korzeni, Warszawa.

Krysiński A. (1928), Liczba i rozmieszczenie Białorusinów w Polsce, „Sprawy Narodowościowe", z. 3-4.

Makarski W. (1996), Pogranicze polsko- ruskie do połowy wieku XIV. Studium językowo-etniczne, Lublin.

Misiejuk D. (2004), Tożsamość ukraińska w Polsce: odtwarzanie czy tworzenie? Uwagi o kreacji tożsamości mniejszościowej, [w:] Z. Jasiński, T. Lewowicki (red.), Kultura mniejszości narodowychi i grup etnicznych w Europie, Opole.

Ryżyk E., Kuprianowicz G. (1992), Kronika podlaska „Nad Buhom i Narwoju”, nr 3.

Sadowski A. (1995), Pogranicze polsko-białoruskie. Tożsamość mieszkańców, Białystok.

Sadowski A. (2006), Kapitał społeczny mieszkańców miasta, Białystok.

Sadowki A. (2007), Naród kulturowy jako kategoria badawcza socjologii narodu, [w:] A. Sakson (red.), Ślązacy, Kaszubi, Mazurzy i Warmiacy - między polskościa a niemieckością, Poznań.

Sajewicz M. (2008), Zagadnienie przynależności etniczno-językowej prawosławnych mieszkańców powiatu hajnowskiego na Białostocczyźnie, [w:] M. Stepaniuk (red.), Gwary Północnego Podlasia, Bielsk Podlaski.

Tomaszewski J. (1985), Rzeczpospolita wielu narodów, Warszawa.

Wakar W. (1917), Rozwój terytorialny narodowości polskiej, cz. 2: Statystyka narodowościowa Królestwa Polskiego, Warszawa.

Wasilewski L. (1927), Istotna liczba Ukraińców w Polsce, „Sprawy Narodowościowe”, z. 5-6.

Wiśniewski J. (1977), Osadnictwo wschodniosłowiańskie Białostocczyzny - geneza, rozwój oraz zróżnicowanie i przemiany etniczne, „Acta Baltico- Slavica”, t. 4. 


\section{SUMMARY}

\section{Transformation of the identity of national minority in conditoon of essentail political} changes. On the exemple of ukrainian minority in Podlaskie Voivodeship

In the article the author is trying to show the process of complicating national structures and the evolution of the national identity on the area of the borderland. These changes are happening in progressing social, cultural and political transformations which touched these areas upon last decades. An Ukrainian minority in podlaskie voivodeship is a subject of these transformations. Within the last decades this population was subject of intense and characteristic identity transformations. It is interesting to trace the evolution of the national identity of Ukrainian minority in podlaskie voivodeship and simultaneously state that this proces still didn't end. The article is leaning on two rounds of own examinations as well as researches conducted in the past by historians and linguists concerning areas of today's podlaskie voivodeship.

KEYWORDS: national minority, ethnic minority, reviving national awareness, national identity 